Selcuk Journal of Agriculture and Food Sciences

http://sjafs.selcuk.edu.tr/sjafs/index

Research Article
SJAFS

(2021) 35 (3), 202-209

e-ISSN: 2458-8377

DOI:10.15316/SJAFS.2021.249

\title{
An Economic Analysis of Plums Production: The Case of Gradacac, Bosnia And Herzegovina
}

iD Sumedina SPAHIC-VUKOJEVIC ${ }^{1}$, ID Mithat DIREK ${ }^{1}$

${ }^{1}$ Selcuk University, Faculty of Agriculture, Department of Agricultural Economics, Konya, Turkey

\begin{tabular}{l}
\hline ARTICLE INFO \\
\hline Article history: \\
Received date: 17.06 .2021 \\
Accepted date: 21.09 .2021 \\
\hline
\end{tabular}

Keywords:

Farm Capital

Fruit Production

Gross Profit

Gross Production Value

Plum Production

\begin{abstract}
The production of plums has an important economic significance in $\mathrm{BiH}$. By this product, Bosna Hersek is recognizable for a long time, since significant quantities of fresh and dried plum, besides for supply of domestic market, have been exported to the European and Global market. Municipality of Gradacac has a significant role in all of this, because takes the first place in the production of plums in $\mathrm{BiH}$. This study investigates the economics of production of Plums in Gradacac. For this purpose, primary data were collected from plums farmers using a (multistage random sampling technique / stratified randomly sampling technique/simple random sampling technique). Date were analysed using economic analysis and descriptive statistical techniques. Results show that, the capital structure of the enterprises surveyed in the research area was classified according to their functions and the average active capital of the enterprises was calculated as $284.125,49 \mathrm{KM}$ (Average $1 \$=1,67 \mathrm{KM}$ in 2017). $91,76 \%$ of this is the farm capital and $8,44 \%$ is the fixed enterprise capital. The average of gross production value realized at the surveyed farms is 17366,41 $\mathrm{KM}$, of which the value of the cattle production belongs to $19,75 \%$, while the plum's production value is $80,25 \%$.
\end{abstract}

\section{Introduction}

Plums are unusual in being independently domesticated on three different continents - Europe, Asia and North America. Most plums in commercial productions today are classified as European (hexaploid) or Japanese (diploid) types (Hui 2006).

Plum is orchard's culture that grows the most at the area of B\&H. The production has based on a selection of Čačak's cultivation program and cultivator Stenley, with the gradual introduction of German's cultivators by the modernization of plum's production. Given that the biggest problem in the plum production is viral disease known as "šarka", more and more varieties are being introduced in production with a recommendation of resistance or tolerance to the same one (Kurtovic et al 2013).

The plum's production enables entry into new markets, by increasing employment and the degree of capacity use in the agriculture and the food industry, which encourages the development of entrepreneurship and the national economy (Prodanovic 2015). Therefore, it is important to emphasize the development of fruit's production and the application of modern technologies to achieve better economic effects (Blagojević and Božić 2012).

\footnotetext{
*Corresponding author email:sumedina.spahic@hotmail.com
}

Therefore, plum in Bosnia and Herzegovina takes the first place per sown areas and production. However, the low level of technics and technology in production of plum has reflected in relatively small and unstable yields per tree, as well as oscillations in annual production. There is a large number of old (oronulative) trees, as well as plum's trees, which have raised on inadequate land due to irregular yieldedness and poor productivity. The present production could be achieved from smaller surfaces than currently is case, thus releasing the surfaces for other cultures. The largest part of the produced plum in Bosnia and Herzegovina has exported. A large amount of produced plum goes to plum's brandy while the remaining has processed into dry plum and plum's jam.

The average annual production of plum in Bosnia and Herzegovina for the period 2008-2017 year was $133.887,60$ tons. Production of plum varied over the years, with the highest number being recorded in 2013 year of 226.898 tones, and the lowest in 2014 year was 74,075 tones. Production in the last observed year (2017) was 74.398 tons, which is 84.181 tons lowest than in 2016 year when it amounted to 131.579 tons.

Due to favourable climatic conditions, Bosnia and Herzegovina belongs to the top of the European countries. Such climatic conditions are suitable for the cultivation of various fruit crops. This allows an export of a significant part of the total country's production of fruits to the European countries. The increase in export 
of the plum, results in an increase in income, for a country that is specialized in this type of production. The plum production has increased in the world as same as in our neighboring countries. Due to this fact, it is necessary to specialize our production of plum in order to be competitive with the other countries.

Gradacac is a traditional fruit-growing region. Thanks to the favorable agropedological properties of agricultural land and favorable climatic conditions, the Municipality of Gradačac takes the lead in the agricultural production of the Tuzla Canton, especially in the field of fruit growing (fruit production) (Spahic 2011).

Gradacac according to Kepen's climatic classification, belongs into the $\mathrm{C}$ climate zone (moderately warm and moody climate). Therefore, Gradacac has a moderate continental climate (Custovic 2013). According to the economic importance, production of plum, take the first place, among all fruit production. Plum (Prunus domestica) belongs to the Rose family (Rosaceae) and to the genus Prunus, which includes all stone fruit. Among all stone fruits which are growing in the area of Gradacac municipality, plum is the most important and the most demand fruit crop, therefore for the production of this culture, it gives a special importance (Kurtovic et al 2008).

The truth is that we are a country which, due to a poor agricultural structure, is not able to produce a large amount of plum, and in this way, surely we cannot be competitive with developed countries, where plum is produced on much larger agricultural plots. Therefore, quality is our best means, how to become competitive with the countries where plums are produced in much larger quantities. Plum production in the area of Gradacac municipality is characterized by a number of specificities. First of all, the initial investments were quite high, the capital flow was pretty slow, and therefore, the high of yields initially were not satisfactory. Due to the hard work of efforts of farmers, plum production has an intense character. However, due to inadequate political structure and unfinished adequate strategies for this fruit crop, we cannot say that the producers of plums in this area provide regular and high yields, and continuous quality of the plum which could result in a significant profit.

\section{Materials and Methods}

In order to realize the goals of this work in an adequate manner, appropriate methods will have to be applied, both for the collection of data and also for their processing. The methods that will be used in the preparation of this research are: survey method, method of interviewing and statistical method.

For the area of research, it was selected the Municipality of Gradacac. Gradadac area has been selected due to the purpose of sampling, according to the fact that this area constitutes $48.57 \%$ of the total plum production, easy transportation and limited financial funds. Sampling is the process of selecting of subset of individuals from the community, or sampling is the process of selecting single individual of the basic set. (Oğuz and Karakayacı, 2017).

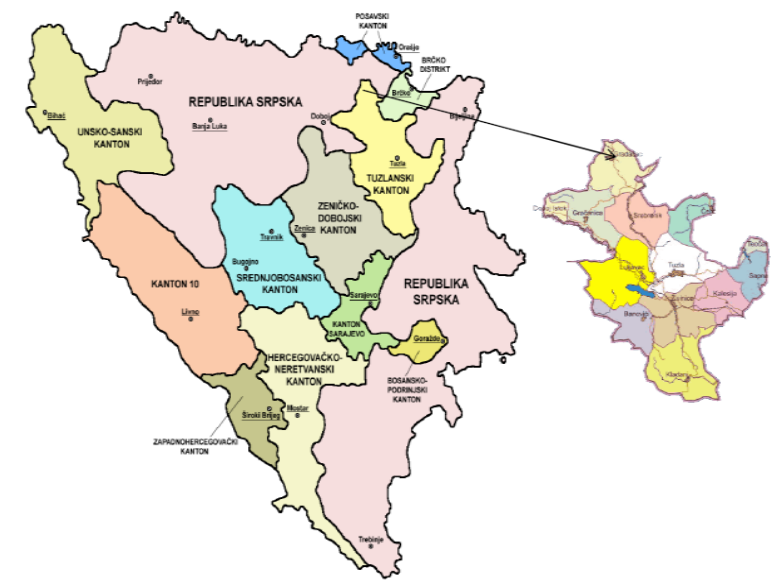

Figure 1

Administrative division of Bosnia and Herzegovina

Based on the results of the interviews in the Gradacac Municipality, it was determined that there is no definitive information regarding on the percentage of plum producers, and the information obtained from the authorities indicated that this rate was half. According to a simple random sampling method, the number of samples, which should be taken is calculated using the following formula. The formula used for this purpose is given below (Güneş and Arıkan 1988).

$\mathrm{n}=\frac{N(p q)}{(N-1) D^{2}+(p q)}$

In this formula:

$\mathrm{n}$ : sample volume

$\mathrm{d}$ : allowable margin of error (accepted margin of error $10 \%)$

t: The table value that corresponds to a $95 \%$ confidence level.

$\mathrm{p}$ - the ratio of the unit studied in the population to 0.50 .

$\mathrm{q}$ - refers to the probability of occurrence of the incident $(q=1-p)$.

According to this study, a survey was conducted with a total of 65 plum producers.

\subsection{Method used in socio-economic analysis of an enterprises}

As the examined enterprises were taken as a whole, the distribution of capital according to their functions was applied (Açıl and Demirci 1984).

\subsubsection{Elements of active and passive capital}

Capital in agricultural farms is classified according to different criteria. The classification of capital according to liquidity is more appropriate for the analysis of capital (Erkuş et al 1995). In this study, the following classification is used according to the liquidity of capital.

I. Active capital 
A. Agricultural capital

- land capital

- land melioration capital

- construction capital

- plant capital

- hunting and fishing capital

B. Capital of economy

1. Capital of permanent funds

- equity capital

- capital of tools and machines

Capital of working assets

- material capital

- money capital

II. Passive capital

- Foreign capital (debts)

- In the form of legal rights and short-term divisions

\subsection{Socio-economic indicators}

In the economic analysis of plums in the Gradacac region, the following methods were used.

\subsubsection{Gross production value (GPV)}

Gross production value, also called the gross value of production, the total value of production was realized in the accounting period (Çetin 2003). The value of agricultural products, produced on the farm, the value of plant and animal production estimated at farm prices, results in the total gross production value on the farm (Oğuz and Bayramoğlu 2018).

\subsubsection{The total cost}

The total costs examined for agricultural activities in the enterprises, will be calculated separately as variable and fixed costs (Oğuz and Bayramoğlu 2015).

\section{Total Cost $=$ Variable cost + Fixed cost}

\subsubsection{Pure profit}

After the costs are found, the total costs from Gross revenue, the remaining part is called the interest of the active capital. Total production costs will be deducted from Gross revenue and the pure profit will be found (Çetin 2003).

Pure profit $=$ Gross revenue - Total Cost

\subsubsection{Gross profit}

Gross profit is calculated by subtracting variable costs from gross production value. Gross profit is considered as an important measure for proving the competitiveness and success of the production activity (Erkuş et al 1995).

Gross profit $=$ Gross production value - Variable costs

\subsubsection{Agricultural income}

Agricultural income is called the success criterion of the enterprises. The following equations are used in the calculation of agricultural income.

Agricultural income $=$ Pur Profit $-($ Debt interest + Rents) + Family Labor Force Fee Return

\subsubsection{Family Income}

Income earned during the year by family members and agricultural producers. It covers the incomes both in and out of the enterprise and the non-agricultural income.

2.2.7. The financial and economic profitability of the enterprises surveyed

\section{a) Rentability factor}

The total income of the enterprise is Gross revenue and the income of capital is pure profit, the relation between these two measures is a factor of profitability (Oğuz and Bayramoğlu 2015).

Rantability factor $(R F)=$ Pure Profit $/$ Gross revenue

b) Economic rantability

It is calculated in order to measure the profitability of the enterprise. The total capital of the enterprise (active capital) and the resulting pure profit are proportioned.

\section{Economic Rantability = Pure Profit / Total Farms Capital $* 100$}

c) Capital turnover rate

Another criterion of success that can be used to measure the success of a company (Oğuz and Bayramoğlu 2018).

Capital turnover rate $=$ The gross production val ue/Total farm capital $* 100$

\section{Results and Discussion}

The municipality of Gradacac is a suitable area for fruit production, especially when it comes to plum because it has high-quality resources (land, water, air) and experienced producers. The economy of plum's production has determined by many factors, and essential are as follow: choice of sorts, locations, application of agro and biotechnical measures, production costs and market prices.

\subsection{Capital Structure in the farms}

In agricultural enterprises, capital helps net revenues increase directly (Oğuz and Yener 2017). Active capital is classified as farm capital and enterprise capital. Farm capital consists of land, land improvement, building, plant, hunting and fish capital. The enterprise capital is divided into two groups as fixed enterprise capital and revolving enterprise capital. Fixed enterprise capital consists of livestock capital, tool and machine capital; and the revolving capital consists of material capital and money capital (Oğuz and Bayramoğlu, 2015)

The following table presents distribution (KM) and ratios $(\%)$ of active capital in the surveyed farms. The value of total active capital according to the size of the farm is different. $284125.49 \mathrm{KM}$ of active capital has been identified per farms. $91.76 \%$ of this is the farm capital and $8.44 \%$ is the fixed enterprise capital. As the enterprise increases, active capital per enterprise increases. The highest value of total active capital is in 
the group of farms of 30 decare and more and amounted to $623995.63 \mathrm{KM}$, in the group of farms of 11-30

Table 1

Distribution (KM) and ratios (\%) of active capital in the surveyed farms

\begin{tabular}{|c|c|c|c|c|c|c|c|c|c|}
\hline \multirow{3}{*}{\multicolumn{2}{|c|}{ Capital groups }} & \multicolumn{6}{|c|}{ Farm Size Groups (da) } & \multirow{2}{*}{\multicolumn{2}{|c|}{ Average }} \\
\hline & & \multicolumn{2}{|c|}{$0-10$} & \multicolumn{2}{|c|}{$11-30$} & \multicolumn{2}{|c|}{$31+$} & & \\
\hline & & KM & $\%$ & KM & $\%$ & KM & $\%$ & KM & $\%$ \\
\hline \multirow{5}{*}{$\begin{array}{l}\text { Farms } \\
\text { capital }\end{array}$} & Land capital & 15881.00 & 10.28 & 50667.00 & 18.49 & 208750.00 & 36.98 & 55673.80 & 21.40 \\
\hline & LIC & 266.66 & 0.17 & 1508.33 & 0.55 & 1125.00 & 0.20 & 945.38 & 0.36 \\
\hline & Building capital & 105574.08 & 68.31 & 130796.67 & 47.73 & 168287.50 & 29.81 & 124933.85 & 48.02 \\
\hline & Plant capital & 32824.61 & 21.24 & 91061.30 & 33.23 & 186401.88 & 33.02 & 78604.90 & 30.21 \\
\hline & Total & 154546.35 & $\begin{array}{c}100.00 \\
91.83 \\
\end{array}$ & 274033.30 & $\begin{array}{c}100.00 \\
92.04\end{array}$ & 564564.38 & $\begin{array}{c}100.00 \\
90.48 \\
\end{array}$ & 260157.93 & $\begin{array}{c}100.00 \\
91.76 \\
\end{array}$ \\
\hline \multirow{3}{*}{$\begin{array}{l}\text { Fixed } \\
\text { enterprises } \\
\text { capital }\end{array}$} & Livestock capital & 3555.23 & 25.84 & 5798.34 & 24.47 & 7337.50 & 12.35 & 5056.02 & 21.10 \\
\hline & TM & 10203.70 & 74.16 & 17900.00 & 75.53 & 52093.75 & 87.65 & 18911.54 & 78.90 \\
\hline & Total & 1375893 & $\begin{array}{c}100.00 \\
8.17\end{array}$ & 23698.34 & $\begin{array}{c}100.00 \\
7.96\end{array}$ & 59431.25 & $\begin{array}{c}100.00 \\
9.52\end{array}$ & 23967.56 & $\begin{array}{c}100.00 \\
8.44\end{array}$ \\
\hline \multicolumn{2}{|c|}{ Total active capital } & 168305.28 & 100.00 & 297731.64 & 100.00 & 623995.63 & 100.00 & 284125.49 & 100.00 \\
\hline
\end{tabular}

LIC: Land improve capital, TM: Tools machines, Resources; Calculated by the author according to research results.

As can be seen in the table, the share of the farm capital in the active capital is much more than the share that should be in a normal enterprise. Besides, the rates of plant, land improvement, livestock capital are very low. This formation of active capital is considered as a situation that affects business success negatively (Erkus 1979). $91.76 \%$ of the active capital in the enterprises surveyed is farm capital, $8.44 \%$ is fixed enterprise capital. The largest share of active capital is obtained from building $(43.97 \%)$. This is followed by plant capital (27.67\%), land capital (19.59\%) and tool and machine capital $(6.66 \%)$.

\subsection{Gross production value (GPV)}

Under the term value of the stone fruit it is considered the market value of the products obtained. It is Table 3

Gross production value (GPV) of plum by type of sales at the surveyed farms

\begin{tabular}{|c|c|c|c|c|c|c|c|}
\hline \multirow{2}{*}{ Farm Size Groups } & \multicolumn{6}{|c|}{ Plum's production } & \multirow{2}{*}{ Total } \\
\hline & Fresh plum & $\%$ & Dry plum & $\%$ & Brandy & $\%$ & \\
\hline $0-10$ & 5707.04 & 97.50 & 74.07 & 1.27 & 72.22 & 1.23 & 5853.34 \\
\hline $11-30$ & 13116.07 & 91.17 & 833.33 & 5.79 & 436.67 & 3.04 & 14386.07 \\
\hline $31+$ & 38150.00 & 99.03 & 0.00 & - & 375.00 & 0.97 & 38525.00 \\
\hline Average & 13119.57 & & 415.38 & & 277.69 & & 13812.65 \\
\hline$\%$ & 94.98 & & 3.01 & & 2.01 & & 100.00 \\
\hline
\end{tabular}

From the data in the table it can be stated that the largest quantity of plums at the surveyed farms sells in the fresh state $(94.98 \%)$, dry plum has sold in very small quantities of only $3.01 \%$ while a small part of the plum has processed and sold in plum's brandy $2.01 \%$.

Table 4

Gross production value (GPV) of total production of plum at the surveyed farms

\begin{tabular}{lccc}
\hline \multirow{2}{*}{ Farm Size Groups } & \multicolumn{4}{c}{ The gross production value of total production of plum (KM) } \\
\cline { 2 - 4 } & Sales Value & GPV of plums, which is consumed by the family and workers & Total \\
\hline $0-10$ & 5853.34 & 129.63 & 5982.97 \\
$11-30$ & 14386.07 & 150.60 & 14536.67 \\
$31+$ & 38525.00 & 0.00 & 38525.00 \\
Average & 13812.65 & 123.35 & 13936.00 \\
$\%$ & 99.11 & 0.89 & 100.00 \\
\hline
\end{tabular}

From the data in the table it can be estimated that the average of total gross production value produced by the examined farms was $13936.00 \mathrm{KM}$. In this study, $\$ 1=1.67$ Bosnia and Herzegovina convertible mark obtained by multiplying the amount of realized yields with the market price.

From the table, it can be stated that the average of gross production value of plum's at the surveyed farms is $13812.65 \mathrm{KM}$. As the size of plum's production has increased, the value of production is increasing.

The following table shows the gross production value of plum's at the surveyed farms by type of sales.

Table 2

Gross production value (GPV) of plum's

\begin{tabular}{cc}
\hline Farm Size Groups (da) & GPV (KM) \\
\hline $0-10$ & 5853.34 \\
$11-30$ & 14386.07 \\
$31+$ & 38525.00 \\
Average & 13812.65 \\
\hline
\end{tabular}
value of total production of plum at the surveyed farms. decare, the total value of capital was 297731.64 KM, while on farms 0-10 dunums 168305.28 KM. 
Thus, the highest value of produced slivers was achieved by selling $99.11 \%$, while the value of the slurry was recovered and processed at the farm $0.89 \%$. The following table shows the gross production value in livestock production achieved at the surveyed farms.

The following table shows the gross production value (GPV) achieved at the surveyed farms.

From the data in the Table 5, it can be seen that the average of gross production value realized at the sur-

Table 5

Gross production value (GPV) realized at the surveyed farms

\begin{tabular}{lccc}
\hline Farm Size Groups (da) & GPV-Livestock & GPV-Plum & Total GPV \\
\hline $0-10$ & 2808.70 & 5982.97 & 8791.67 \\
$11-30$ & 3238.21 & 14536.67 & 17774.88 \\
$31+$ & 6249.38 & 38525.00 & 44774.38 \\
Average & 3430.40 & 13936.00 & 17366.41 \\
$\%$ & 19.75 & 80.25 & 100.00 \\
\hline
\end{tabular}

Table 6

The gross revenue by groups of the farms (KM)

\begin{tabular}{|c|c|c|c|c|c|c|c|c|}
\hline & \multicolumn{8}{|c|}{ Farm Size Groups } \\
\hline & \multicolumn{2}{|c|}{$0-10$} & \multicolumn{2}{|c|}{$11-30$} & \multicolumn{2}{|c|}{$31+$} & \multicolumn{2}{|c|}{ Average } \\
\hline & $\mathrm{KM}$ & $\%$ & KM & $\%$ & $\mathrm{KM}$ & $\%$ & $\mathrm{KM}$ & $\%$ \\
\hline Gross production value & 8791.67 & 73.52 & 17774.88 & 81.92 & 44774.38 & 89.87 & 17366.41 & 82.25 \\
\hline Housing rent & 3167.22 & 26.48 & 3923.90 & 18.08 & 5048.63 & 10.13 & 3748.02 & 17.75 \\
\hline Gross revenue & 11958.89 & 100.00 & 21698.78 & 100.00 & 49823.01 & 100.00 & 21114.42 & 100.00 \\
\hline
\end{tabular}

It can be seen from the table that the value of the gross revenue per farms is $21114.42 \mathrm{KM}$.

\subsection{Cost analysis on the farm}

Cost analysis means testing the dynamics and structure of total cost of reproduction and their correlation with other categories or business results. Cost analysis is the basic and integral part of cost-effectiveness analysis. The purpose of cost analysis is to reveal the places and types of costs that can be reduced or avoided and

Table 7

Total cost veyed farms is $17366.41 \mathrm{KM}$, of which the value of the cattle production belongs to $19.75 \%$, while the plum's production value is $80.25 \%$.

\subsection{Gross revenue}

The following table shows the gross revenue by groups of the farm thus achieve better results in the next business period (Gogic 2005).

The following table shows the average amount of total costs at the surveyed farms. From the table, it can be seen that the average amount of total costs are 17933.04 KM. In the enterprises surveyed, variable costs and fixed costs are estimated to be $7630.39 \mathrm{KM}$ and $10302.65 \mathrm{KM}$, respectively. $44.22 \%$ of total cost is variable costs and $55.78 \%$ is due to fixed cost.

\begin{tabular}{|c|c|c|c|c|c|c|c|c|}
\hline & \multicolumn{6}{|c|}{ Farm Size Groups (da) } & \multirow{2}{*}{\multicolumn{2}{|c|}{ Average }} \\
\hline & \multicolumn{2}{|c|}{$0-10$} & \multicolumn{2}{|c|}{$11-30$} & \multicolumn{2}{|c|}{$31+$} & & \\
\hline & KM & $\%$ & KM & $\%$ & KM & $\%$ & KM & $\%$ \\
\hline Total Variable Cost & 3150.54 & 35.93 & 7037.86 & 40.25 & 23434.20 & 55.78 & 7441.14 & 44.22 \\
\hline Total Fixed Cost & 6117.54 & 64.07 & 11291.14 & 59.75 & 20720.58 & 44.22 & 10302.65 & 55.78 \\
\hline Total Cost & 9268.08 & 100.00 & 18329.00 & 100.00 & 44154.78 & 100.00 & 17743.79 & 100.00 \\
\hline
\end{tabular}

The following table shows a review of the total production cost.

Table 8

14206.27 KM of total Production Cost is Intrest on active capital and $17743.79 \mathrm{KM}$ is due to total cost (Table 8).

The total production expenses

\begin{tabular}{ccccc}
\hline & \multicolumn{3}{c}{ Farm Size Groups (da) } & \multirow{2}{*}{ Average } \\
\cline { 2 - 4 } & $0-10$ & $11-30$ & $31+$ & KM \\
\cline { 2 - 4 } & $\mathrm{KM}$ & $\mathrm{KM}$ & 31199.78 & 14206.27 \\
Interest on active capital & 8415.26 & 14886.58 & 44154.78 & 17743.79 \\
Total Cost & 9268.08 & 18329.00 & 75354.56 & 31950.06 \\
Total Production Cost & 17683.34 & 33215.58 & & \\
\hline
\end{tabular}

3.5. Pure profit

Pure profit in business analysis is defined as the best measure of success. (Oğuz and Bayramoğlu, 2018). The following table gives the determined indi- cators of the pure profit, i.e. the realized pure profit at the farms, and the average amount of pure profit.

From the Table 9, it can be seen that the average amount of pure profit is $3370.63 \mathrm{KM}$. 
Table 9

Pure profit at the surveyed farms (KM)

\begin{tabular}{|c|c|c|c|c|c|c|c|c|}
\hline & \multicolumn{8}{|c|}{ Farm Size Groups (da) } \\
\hline & \multicolumn{2}{|c|}{$0-10$} & \multicolumn{2}{|c|}{$11-30$} & \multicolumn{2}{|c|}{$31+$} & \multicolumn{2}{|c|}{ Average } \\
\hline & KM & $\%$ & KM & $\%$ & KM & $\%$ & KM & $\%$ \\
\hline Gross revenue & 11958.89 & 100.00 & 21698.78 & 100.00 & 49823.01 & 100.00 & 21114.42 & 100.00 \\
\hline Total Cost & 9268.08 & 74.76 & 18329.00 & 77.72 & 44154.78 & 83.63 & 17743.79 & 78.80 \\
\hline Pure profit & 2690.81 & 25.24 & 3369.78 & 22.28 & 5668.23 & 16.37 & 3370.63 & 21.20 \\
\hline
\end{tabular}

\subsection{Gross profit}

Gross Profit is obtained by subtracting total variable costs from Gross Production Value (GPV) (Kiral et Table 10

Gross profit in the surveyed farms

\begin{tabular}{ccccccccc}
\hline & \multicolumn{7}{c}{ Farm Size Groups (da) } \\
\cline { 2 - 9 } & \multicolumn{2}{c}{$0-10$} & \multicolumn{2}{c}{$11-30$} & \multicolumn{2}{c}{$31-+$} & \multicolumn{2}{c}{ Average } \\
\cline { 2 - 9 } & KM & $\%$ & KM & $\%$ & KM & $\%$ & KM & $\%$ \\
\hline GPV & 8791.67 & 100.00 & 17774.88 & 100.00 & 44774.38 & 100.00 & 17366.41 & 100.00 \\
Total variable costs & 3150.54 & 35.84 & 7037.86 & 39.59 & 23434.20 & 52.34 & 7441.14 & 42.85 \\
Gross profit & 5641.13 & 64.16 & 10737.02 & 60.41 & 21340.18 & 47.66 & 9925.27 & 57.15 \\
\hline
\end{tabular}

\subsection{Agricultural income}

Agricultural income is called a criterion of success of business (Oğuz and Bayramoğlu 2018). The table below shows the calculated agricultural income at the surveyed farms.

Table 11

Agricultural profit in the surveyed farms

\begin{tabular}{|c|c|c|c|c|}
\hline & \multicolumn{3}{|c|}{ Farm Size Groups (da) } & \multirow{2}{*}{ Average } \\
\hline & $0-10$ & $11-30$ & $31+$ & \\
\hline Pure profit & 2690.81 & 3369.78 & 5668.23 & 3370.63 \\
\hline Family Labor Force Fee Return & 1069.44 & 2199.17 & 3545.63 & 1895.62 \\
\hline Agricultural income & 3760.25 & 5568.95 & 9213.86 & 5266.25 \\
\hline
\end{tabular}

\subsection{Family income}

Table 12

Total Family income

\begin{tabular}{|c|c|c|c|c|c|c|c|c|}
\hline & \multicolumn{6}{|c|}{ Farm Size Groups (da) } & \multirow{2}{*}{\multicolumn{2}{|c|}{ Average }} \\
\hline & \multicolumn{2}{|c|}{$0-10$} & \multicolumn{2}{|c|}{$11-30$} & \multicolumn{2}{|c|}{$31+$} & & \\
\hline & KM & $\%$ & KM & $\%$ & KM & $\%$ & KM & $\%$ \\
\hline Agricultural income & 3760.25 & 30.15 & 5569.95 & 36.45 & 9213.86 & 46.04 & 5266.71 & 35.84 \\
\hline $\begin{array}{l}\text { Non-agricultural } \\
\text { income }\end{array}$ & 8712.89 & 69.85 & 9709.63 & 63.55 & 10800.00 & 53.96 & 9429.80 & 64.16 \\
\hline Total Family income & 12473.14 & 100.00 & 15279.58 & 100.00 & 20013.86 & 100.00 & 14696.51 & 100.00 \\
\hline
\end{tabular}

\subsection{Financial and Economical Profitability in the Surveyed farms}

The profitability indicators determine the degree of economic efficiency of production, ie the effectiveness

Table 13

Rentability factor

\begin{tabular}{|c|c|c|c|c|}
\hline & \multicolumn{3}{|c|}{ Farm Size Groups (da) } & \multirow{2}{*}{ Average } \\
\hline & $0-10$ & $11-30$ & $31+$ & \\
\hline & KM & KM & $\mathrm{KM}$ & $\mathrm{KM}$ \\
\hline Pure profit & 2690.81 & 3369.78 & 5668.23 & 3370.63 \\
\hline Gross revenue & 11958.89 & 21698.78 & 49823.01 & 21114.42 \\
\hline Rentability factor & 22.50 & 15.53 & 11.38 & 15.96 \\
\hline
\end{tabular}

The table below shows the calculated total family income. Thus, the total family profit per farm is 14696.51 KM. bility shows how much of each invested 100 units of money earns pure profit or income (Ranogajec 2009). realized at the surveyed farms is $5266.25 \mathrm{KM}$ (Table 11). the surveyed farms. In the enterprises surveyed, enterprises-average gross profit was 9925.27 KM.

It can be seen from the table that the average profit 
Thus, the average renatability of production at farms is (15.96), which means that every $100 \mathrm{KM}$ of production value has a profit of $15.96 \mathrm{KM}$. In the fol-

Table 14

Economic rentability (\%) lowing table, has been given the economic rentability per groups of farms for 2017.

\begin{tabular}{lcccc}
\hline & \multicolumn{3}{c}{ Farm Size Groups } & \multirow{2}{*}{ Average } \\
\cline { 2 - 4 } & $0-10$ & $11-30$ & $31+$ & 3370.63 \\
Net profit & 2690.81 & 3369.78 & 5668.23 & 284160.57 \\
Total farm capital & 168304.58 & 297806.64 & 623933.13 & 1.19 \\
Economic rentability & 1.60 & 1.13 & 0.91 & \\
\hline
\end{tabular}

The average economy of the farms is $1.19 \mathrm{KM}$, which means that with each $1 \mathrm{KM}$ the realized value of production was $1.19 \mathrm{KM}$.

Table 15

Capital turnover rate

\begin{tabular}{|c|c|c|c|c|}
\hline & \multicolumn{4}{|c|}{ Farm groups } \\
\hline & $0-10$ & $11-30$ & $31+$ & Average \\
\hline & KM & KM & KM & KM \\
\hline The gross production value & 8791.67 & 17774.88 & 44774.38 & 17366.41 \\
\hline Total farm capital & 168304.58 & 297806.64 & 623933.13 & 284160.57 \\
\hline Capital turnover rate & 5.22 & 5.97 & 7.18 & 6.11 \\
\hline
\end{tabular}

The capital turnover rate is calculated within activity (efficiency) ratios. It is calculated by dividing the gross production value by the total enterprise capital. It demonstrates how effectively the enterprise assets can produce output. The higher the rate, the better. The capital turnover rate of dairy farming enterprises in the research area is $6.11 \%$ in the average of the enterprises.

\section{Conclusions}

The capital structure of the enterprises surveyed in the research area was classified according to their functions and the average active capital of the enterprises was calculated as $284125.49 \mathrm{KM} .91 .76 \%$ of this is the farm capital and $8.44 \%$ is the fixed enterprise capital.

One of the main factors of the production process is land. A land is a basic condition for performing agricultural production. The average value of the land capital is $55673.80 \mathrm{KM}$. The value of a dunum in the area of Gradacac municipality varies from location to location. So the production plots located near the suburban settlements have a fairly high price compared to plots located in rural areas.

The average of building capital at the surveyed farms is $124933.85 \mathrm{KM}$. The average value of plant capital at the surveyed farms is $78604.90 \mathrm{KM}$. The value of total active capital according to the size of the farm is different. 284125.49 KM of active capital has been identified per farms. $91.76 \%$ of this is the farm capital and $8.44 \%$ is the fixed enterprise capital. As can be seen in the table, the share of the farm capital in the active capital is much more than the share that should be in a normal enterprise. Besides, the rates of plant, land improvement, livestock capital are very low. The capital turnover rate, an important indicator in the success and comparison of the enterprises, is $6.11 \%$.
The following table gives the capital turnover rate by farms.

The average of gross production value of plum's at the surveyed farms is $13812.65 \mathrm{KM}$. that the largest quantity of plums at the surveyed farms sells in the fresh state $(94.98 \%)$, dry plum has sold in very small quantities of only $3.01 \%$ while a small part of the plum has processed and sold in plum's brandy $2.01 \%$.

It's necessary to know how to the plum, which is in the state of consumption, gives an added value, in which form should be sell to customers, how to find customers in order to finally achieve the mutual benefit. Without satisfied customers, i.e. consumers, successful production of the plum cannot be achieved. Therefore, it's very important to develop a successful marketing strategy in order to achieve the efficiency and effectiveness of the production of this fruit crop. Since the consumer preferences, from the year to the year, are very fast change and that producers become more demanding when they buy a food, it is necessary to take a step forward and to consumers offer a new product, not just the one they are used to. Consequently, following the world trends in fruit production, producers could achieve very high success by offering consumers a value added product. Also, it's known that the plum is a fruit crop which cannot store fresh on room temperature for a long time, unless it`s stored in cold storage for a shorter period of time. It's necessary to process the plum and offer to consumer in some new shape, packing in order to production as well as consumption should be successful.

\section{References}

Açıl F (1977). Memleketimizde Tarımsal Ürün Maliyetlerinin Hesaplanmas1, Ankara Üniversitesi Ziraat Fakültesi Yayın No.665, 2. Bask1, Şark Matbaası, Ankara.

Açıl AF, Demirci R (1984). Tarım ekonomisi dersleri, Ankara Üniversitesi Ziraat 
Fakültesi Yayınları, Ankara.

Blagojević R, Božić V (2012). Tehnologija proizvodnje šljive, Kancelarija za program podrške u privatnom sektoru za podršku sektoru voćarstva i bobičastog voća u Južnoj Srbiji, Nis.

Çetin B (2003).Tarımsal Finansman, Uludağ Üniversitesi Ziraat Fakültesi Ders Notu No: 97.

Custovic H (2013). Studija upotrebne vrijednosti zemljista za podrucje Opstine Gradacac, Poljoprivredno prehrambeni fakultet u Sarajevu, Sarajevo.

Erkuş A (1979). Ankara ili Yenimahalle ilçesinde kontrollü kredi uygulaması yapılan tarım işletmelerinin planlanması üzerine bir araştırma, A.Ü.Z.F Yayınları No:709, Ankara.

Erkuş A, Bülbül M, Kıral T, Açıl AF, Demirci R (1995). Tarım Ekonomisi, Ankara Üniversitesi Ziraat Fakültesi, Eğitim, Araştırma ve Geliştirme Vakfı Yayınları No: 5, Ankara.

Gogić P (2005). Teorija troškova sa kalkulacijama - u proizvodnji i preradi poljoprivrednih proizvoda.

Günes T, Arıkan R (1988). Tarım Ekonomisi İstatistiği, Ankara Üniversitesi Ziraat Fakültesi Yayını, Yayın No:1049, Ankara.

Kıral T, Kasnakoğlu H, Tatlıdil FF, Fidan H. and Gündoğmuş E (1999). Tarımsal Ürünler İçin Maliyet Hesaplama Metodolojisi ve Veri Tabanı Rehberi. Ankara: Tarımsal Ekonomi Araştırma Enstitüsü Yayın.

Kurtovic M, Karic N, Malicevic A, Gasi F, (2008). Integralna proizvodnja koštičavog voća, načela i argumentacija.", Poljoprivredno - prehrambeni fakultet Sarajevo.

Kurtovic M, Custovic H, Memic S, Drkenda P, Hadziabulic S, Gasi F, Behmen F, Skender A, Ljusa
M, Malicevic A, Kurtovic S, Hodzic A, Kanlic K, Grahic J, Okic A, Uzunovic M, Becirspahic D, Duric S (2013). Vocarska rejonizacija u Federaciji Bosne i Hercegovine', Univerzitet u Sarajevu, Poljoprivredno prehrambeni-fakultet, Sarajevo.

Oğuz C, Bayramoğlu Z (2015). Tarım Ekonomisi, Selçuk Üniversitesi Ziraat Fakültesi, Tarım Ekonomisi Bölümü, Konya.

Oğuz C, Bayramoğlu Z (2018). Tarım Ekonomisi, Selçuk Üniversitesi Ziraat Fakültesi, Tarım Ekonomisi Bölümü, Konya.

Oğuz C, Karakayacı Z (2017). Tarım Ekonomisinde araştırma ve Örnekleme Metodolojisi, Konya.

Oğuz C, Yener A (2017). Analysis of Financial Performance in Dairy Enterprises; The Case Study of Konya, Turkey, Department of Agricultural Economics, Faculty of Agriculture, Selçuk University, 42250 Konya, Turkey.

Prodanović R (2015) Uticaj relevantnih faktora na proizvodnju, preradu i promet organskog voća', Doktorska disertacija, Fakultet za ekonomiju i inženjerski menadžment, Novi Sad, http://scindeksclanci.ceon.rs/data/pdf/2217-5458/2017/221754581702001P.pdf

Ranogajec Lj (2009.). Računovodstvo u poljoprivredi, Interna skripta, Poljoprivredni fakultet u Osijeku, Osijek

Spahic S (2011). Profitabilnost integralne proizvodnje sljive na podrucju opstine Gradacac, Baccalaureat rad, Poljoprivredno Prehrambeni fakultet, Sarajevo.

Yiu H. Hui (2006). Handbook of Food Science, Technology, and Engineering, Opseg 4. 